\title{
Generation Smart Education Learning Process of Blockchain-Based in Universities
}

\author{
Hardjanto Nusantoro ${ }^{1}$, Po Abas Sunarya ${ }^{2}$, Nuke Puji Lestari Santoso ${ }^{3}$, Sabda Maulana ${ }^{4}$ \\ University of Raharja, Indonesia1,2,3,4,4 \\ Jl. Jenderal Sudirman No.40, RT.002/RW.006, Cikokol, Kec. Tangerang, Kota Tangerang, \\ Banten 15117, Indonesia ${ }^{1,2,3,4}$, \\ e-mail: hardjanto.nusantoro@raharja.info', abas@raharja.info², nuke@raharja.info³, \\ sabda@raharia.info ${ }^{4}$
}

Nusantoro, H., Sunarya, . P. A. ., Santoso, N. P. L., \& Sabda Maulana. (2021). Generation Smart Education Learning Process of Blockchain-Based in Universities. Blockchain Frontier Technology, 1(01), 21-34. Retrieved from

DOI: https://journal.pandawan.id/b-front/article/view/7

\begin{abstract}
Smart education in universities can be realized with a comprehensive use of IT infrastructure, various systems that are implemented to run this can take priority of the cloud computing and Internet of Things (IOT) and. Resulting in the need for connectivity into IoT gateways and nodes, as well as implementing an architecture that does not only rely on communication coverage via wireless, but needs to reduce energy consumption in order to save IoT node batteries to maximize performance. The use of such an architecture must prioritize blockchain technology that can provide security, accountability, and data transparency that can be managed by universities. This article discusses the key to early adoption of technology that can develop smart learning with smart learning. After the characteristics of the smart education or university are determined, then the details of the latest communication technologies that are most relevant to the smart education application can be analyzed. In addition, higher education requires learning about the use of blockchain. Therefore, this article will provide useful pointers in planning smart education development, as well as responsible and intelligent developers in the next generation.
\end{abstract}

Keywords: Smart education, blockchain, smart university, edge computing, teaching and learning

\section{Introduction}

The infrastructure of the Internet of Things (IoT) which is managed by smart buildings, smart cities, and smart homes seems very suitable if applied to these smart learning in universities with the aim of being able to interact with sensors and actuation systems[1] [2]. Resembles a smart city, but different from smart homes and buildings, smart learning prioritizes communication in a wide area, because the campus area in which the total area can reach up to thousands of square meters. For example, the article writing university (Universitas Raharja, Indonesia) [3]. This area is still very minimal compared to the largest universities in the world such as: University of California (Los Angeles, America) was deployed in $1.7 \mathrm{~km} 2$, University of Oxford (Oxfordshire, England) covers 45,59 km2, University of Chicago (Chicago, Illinois, United States) occupies 217 acres $(1,1 \mathrm{~km} 2)$. This figure means [4] that smart learning must implement a specific remote communication infrastructure that is connected from inside or outside the room 
to the applied loT gateways, actuators and sensors, and supervise reduced energy consumption so that loT node battery life can be optimized so that it lasts a long time.

A smart education can be managed with a strategic plan (key commitments and priority frameworks). This has an impact, campuses implement various actions by releasing various resources (for example, regarding application services, digital transformation, facilities, educational programs, innovation, and human resources) with the aim of being fundamentally designed to meet the needs of their institutions [5].

Driven by the vision and mission and core values it can be used as a strategic campus plan (more details in section 2). For example, several universities around the world have agreed to make a real contribution to the United Nations Sustainable Development Goals (SDGs) [6].

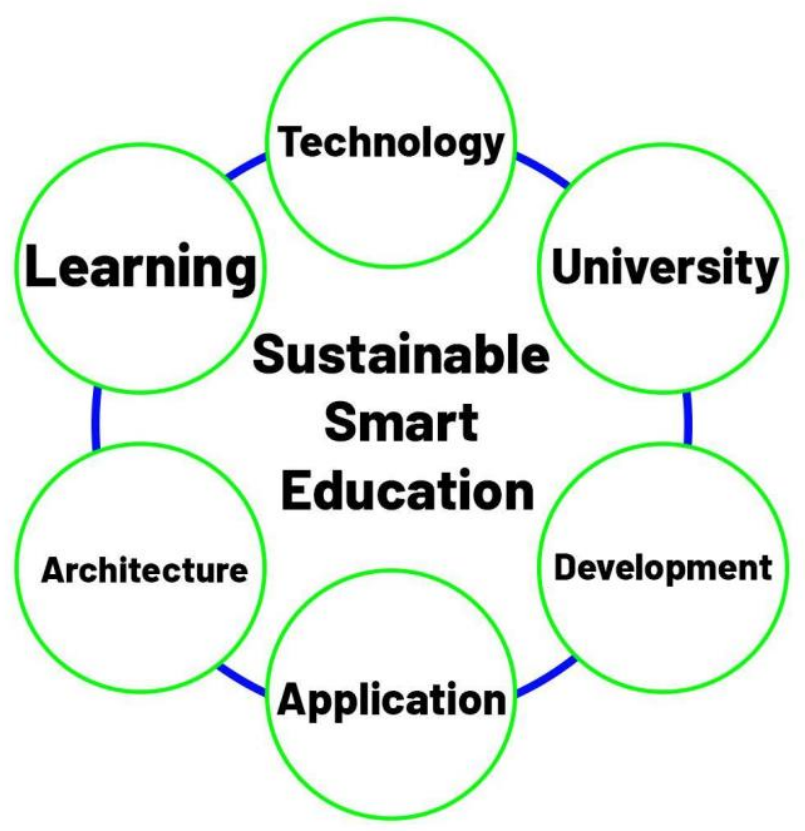

Figure 1. The Sustainable of Smart Education

Resembling a smart city, the services provided by a smart university must be tailored to the needs of the university (such as network services, transportation services, guidance applications, resource consumption efficiency). Apart from that there are several applications that must be specialized in the university environment such as services to analyze their attendance data in lectures and the behavior of students in each lecture activity

The most relevant differences in architecture and technology regarding smart cities can be applied to smart learning:

Homogenic. The application of certain technologies along with certain architectures can be applied to smart learning without any complexities, whereas in smart cities they have to deal with heterogeneity which requires complex solutions to be able to integrate them with many preexisting computing systems.

Infrastructure governance. Usually in smart learning the things related to infrastructure are managed by themselves (i.e., universities), and this makes it easier to deploy communication infrastructure or anything else needed compared to smart cities.Meanwhile, almost all cities have large areas which are managed by private management who do not cooperate with the city government, making it difficult to deploy infrastructure due to the different needs of each person.

Smaller scale. Previously it was mentioned that many campuses have a very large size, although some are not as big as cities, many universities are located in cities and have their own buildings within the city. With the size not too large, it is possible to apply communication 
technology that does not require a very far range. At the same time, the equipment used is much less than smart cities, architecture can be minimized so as to avoid complexity, which usually leads to more development costs and reduced response time.

Studying specifically about the differences in architecture and technology that have been previously mentioned can be used as materials to be able to develop smart learning [7]. In contrast to the previous review of smart learning, introduced as a systematic literature review [8] focusing on identifying specific concepts [9], or promoting specific technologies, Through an analysis of its application, this article can provide a holistic view of the presence of some of the latest technologies that will be designed for the development of smart learning.

Determination of characteristics is the main thing in order to be able to detail all the communication architecture needs to be built from cloud-based which is still traditional and to include the latest technology based on edge computing, implementation of blockchain in architecture can provide cybersecurity and transparency for smart learning, taking the characteristics of the smart university that is most relevant is taken for analysis, the implementation of a smart university can be calculated based on the running of the application, Learning the latest communication technology to be applied outdoors and indoors in smart learning.

The subsequent compilation of this article is as follows. Part 2 will discuss the concept of a smart university and its main features. Part 3 will discuss the potential of blockchain technology in building and deploying higher education applications in smart learning. Section 4 will discuss breakdown of architecture in the field of communication for smart learning. Section 5 will describe the most relevant smart university implementations, focusing on The main application they have developed and communication technologies. Section 6 will discuss the future challenges that will be faced by the developers involved in building a smart university. Finally, section 7 contains a conclusion.

\section{Research Method}

The term smart university is not new. The clever term university has been used in ancient times to pioneer an online digital platform to manage the university context [11], or a series of efforts to improve the quality of intelligence of students[12]. But this article focuses on hardware and software with the aim of providing advanced services to all university students and staff. Another point of smart university refers to developing tools that are meant to fulfill the mission of the university.

- The processes in learning, teaching And those involved in all assessments in the higher education system will be upgraded regularly.

- Developing the latest research and innovation.

- Emphasize communication-based knowledge sharing and a shared vision as university stakeholders (for example students, teachers, non-profit organizations, administration and government).

This point can allow the distinction between a smart university and a smart city from the concept. Despite the fact that a smart university is similar to a smart city in terms of management procedures, which refers to the six smart points [10]:

- Smart people. The involvement of university users is very much needed in terms of teaching and learning and at certain events.

- Smart management. Allows students and university staff to participate if joint decisionmaking is needed or make joint decisions at certain universities.

- Smart atmosphere. Developing an environmental sector with smart solutions to manage available resources in a sustainable manner where the energy produced will be distributed to universities

- Smart entrepreneurship. This field will create productivity and innovation which will be implemented in universities.

- Smart activity. All activities can be monitored from various life factors, including in terms of health, behavior and safety. 
- Smart movement. On the issue of smart learning, this field discusses the best solutions related to the application of systems in universities such as available transportation, environmentally friendly, efficient, and providing smart services.

In summary, Figure 1 describes the main technology smart learning arrangement. The inner circle represents the six smart points discussed previously. The second part of the circle makes the solution of the most relevant and needed technology that is considered to provide the best solution, namely (Unmanned Aerial Vehicle), Augmented Reality (AR), Cyber-Physical Systems (CPSs), and loT. Some of these technologies are also in accordance with the needs of industry 4.0 [14] today, so that their distribution can be done commercially [15]. Cybersecurity also affects the aforementioned technologies as it plays a key role in eliminating potential problems[16]. And the outer and final circle embodies a smart area that can be done in a smart university. Such as, plug-and-play smart object [17], multiple sensors to be applied to a particular smart building [18]. And add a field in the agricultural sector devoted to those growing certain crops with autonomous decision support systems as an aid

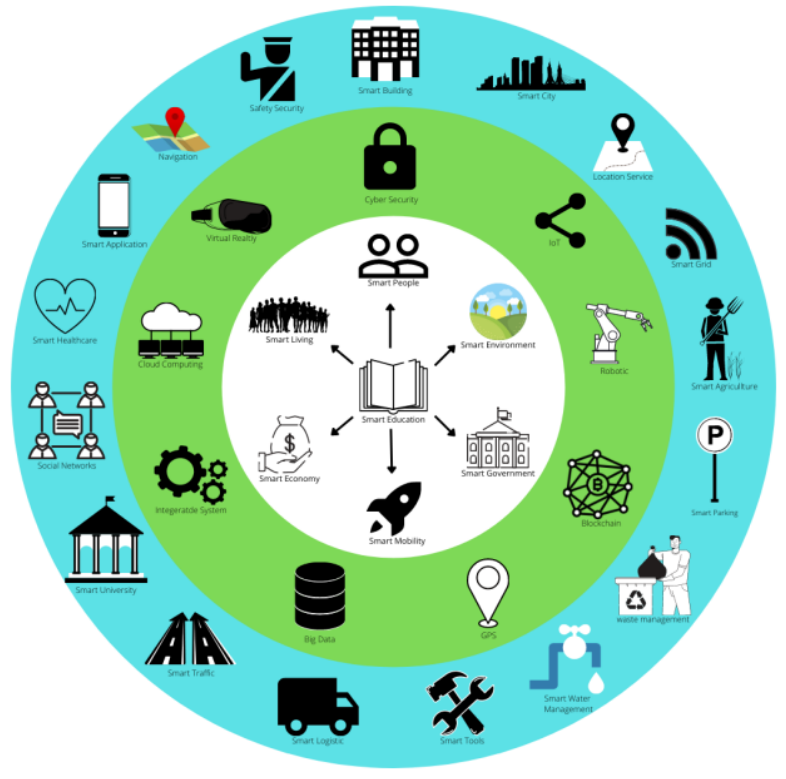

Figure 2. Main fields and technologies of a smart campus.

\subsection{Blockchain for Smart Education in Universities}

Architectural enhancement considerations for both academics [19] [21] and public entities have been previously described using Distributed Ledger Technology (DLT) which is like blockchain [22]. Because it has the ability to exchange data for entities that do not necessarily have a sense of trust in each other, this technology [23] is very suitable to be implemented into a smart learning model at universities [24] [25]. Besides its great use in blockchain data exchange, it is also able to improve the quality of smart university applications because it is able to provide transparency, privacy, security, and data immutability[26]. Decentralized Applications (DApps) based on Peer-to-Peer transactions are also very possible to be developed again using blockchain, through smart contact processes can run automatically and there are also pieces of code autonomously [27].

The rise of blockchain platforms like Bitcoin[28], Etherum [29] , Hyperledger Fabric, can be used in a wide variety of practical applications [30]. However, behind the advantages there is also a drawback where blockchain is not the best solution for an application that a reliable data exchange process. Many cases involve several smart applications whose implementation uses a private network [31], simply by using a traditional database it makes the transaction process run much faster than blockchain [32].

Decision frameworks are needed by developers to determine whether technology such as blockchain is necessary or not [33], such as transparency of transactions, lack of trust between 
entities (respect for governments or banks), and cybersecurity (protection from Denial-attacks) of-Service (DoS)).

Because of the benefits of blockchain that have been discussed previously, the author proposes the use of this blockchain so that it can be applied to a smart learning model in universities. Moreover, blockchain has and has been suggested because it can manage digital copyright information [34], guarantee the authenticity of education certificates [35], verify learning outcomes [36], and increase e-learning interactions [37].

\subsection{Building A Smart Learning}

In general, the previous authors who have discussed smart learning can be categorized as Service Oriented Architectures (SOA) [38] which focuses on two main areas, namely loT and cloud computing[39] [40] which in the process of collecting the analysis process is assisted by Big Data [22]. Intelligent education has referred to cloud computing [41], with services provided by Microsoft (Microsoft Azure) and the COTS hardware the authors deploy the education platform [42] [43]. So that the proposed use of loT can make it easier in terms of architectural deployment, monitoring area access control, monitoring learning applications, and applications to manage all available resources [44].

Some of the researchers who focus on the field of smart education have also proposed alternative paradigms for creating smart learning. For example, author [45] suggests data sharing services without infrastructure. A major update that can be proposed is a floating content node, which can generate data and be shared between users within its area. Other development proposals have been carried out, such as increasing security [46].

The architectural update on smart learning has adapted to various types of use of edge computing paradigms, which have been implemented previously in several other smart services. With the core capabilities of edge computing, it is possible to transfer some of the processing tasks that occur in the cloud, and delegate these tasks to so-called edge devices [47]. Thanks to this advantage the latency response can be minimized while the service can be location aware [48].

The applicant, the author, makes use of blockchain technology to be able to develop their smart learning architecture [49]. Providing services related to bandwidth allocation and content cache can be focused on these devices [50]. Resembling that presented in, the researcher builds intelligent learning services through edge computing devices that are typed to street lights.

Details in the development work [51] [52], the author gives the idea of an intelligent learning platform called WiCloud which refers to mobile edge computing, which allows to access platform servers via mobile base stations or wireless access points. Finally, the application of the smart learning model presented in [53] [55], can take advantage of the fog computation node to provide a memorable experience for users

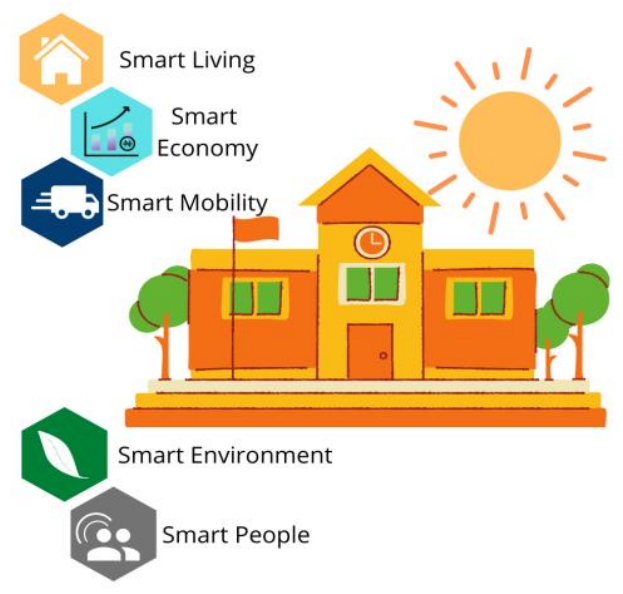

Figure 3. smart education In University 


\section{Result and Discussion}

In the literature, there are still few papers that describe the description of intelligent learning. In particular, smart learners can involve many projects that are run on an open data platform such as using collaborative WiFi.[56] Likewise, in[57] the author describes intelligent learning with cloud computing, SOA, and loT which is managed at the Moncloa International Excellence Campus of Universidad Politécnica de Madrid (Spain). Smart learning is also described in [10], where the author proposes an innovation based on loT and cloud computing to be applied to the Wuhan University of Technology (China) which is intended to support various applications.[58]

Several campuses around the world have also implemented loT as the key to their smart learning such as the West Texas A\&M university[59]. The smart learning that is being carried out focuses on building smart infrastructure as well as the automated intelligent parking system that has been implemented. Another example of a university that has implemented smart learning is the University of Birmingham City (UK), where the main goal is to build a smart architecture that is flexible and scalable.[60]

\section{(a). Smart Education and University Applications}

- Intelligent network and energy monitoring. This application is used to control the generation, distribution and consumption of resources from the available campus energy. In recent years, many of the authors' research has focused on smart [61] networks, and smart energy systems[62].

- Efficient consumption of resources. The use of resources can be monitored through special systems to review how much waste[63], water management, and other solutions that aim to maintain sustainability [64].

- Building monitoring and infrastructure control. The biggest asset in the context of intelligent learners is the state of the infrastructure that is maintained, and can be controlled from anywhere. For example air conditioning systems, university ventilation [65]. Or automate infrastructure through Unmanned Air Vehicles (UAVs).

- Green area monitoring. Monitoring of tree health around the campus can be remotely through an loT sensor-based system [66].

- Behavior monitoring and user manager. Analyzing the behavior patterns of smart education infrastructure and service users can be optimized. For example, user activity, mobility patterns, or social interactions can be determined via smartphone applications, by monitoring communications via WiFi or through media data collection from smartphone sensors, wearables, or even clothing.

- Context sensitive guides and applications. These applications often rely on sensors and rely on actuators that have been scattered throughout the campus so that they can help people by providing useful contextual information and indications of how to achieve their goals. For example, there is interesting research on guidance systems to assist people with visual and hearing impairments [67] to navigate the campus [68]. There is also an augmented reality application that aims to provide relevant contextual information on campus or that is able to guide users through it

- Attendance in class. More sophisticated student monitoring has been proposed, which takes advantage of loT and intelligence to control and monitor student attendance in class [69] and provide them with access to sports facilities.

- Smart health monitoring. Some of the newest applications can be aimed at the health world which can monitor the user's health in real-time [70] or to measure the stress level of students[71].

- The Teaching and Learning application technology embedded in a smart education is used to help students carry out the learning process through their cell phones [63] By carrying out this process, students can have an effective and efficient learning and training experience so that it can be done easily [68] ]. This application can also provide the possibility that teachers can use these learning services through a sophisticated online 
platform, so that they can apply new paradigms such as the Classroom application [69] or amplification.

\section{(b). Communications Technologies}

In the past, researchers have applied a wide variety of technologies to connect remote IOT nodes with smart learning applications [72]. This kind of technology can be very hampered if used in an environment that contains a lot of metal, because it can affect the propagation of signal strength [74].

Example, instructional media design using ZigBee in short to medium distance communication efforts. But from that the ZigBee node functions as a relay, therefore the information that can be exchanged can cover a considerable distance

For example in [75], the proposed blockchain-based smart learning design is due to the transparency of information that can be seen directly and also interconnected. In smart learning, the application can be used indoors or outdoors, but the application has its requirements [76]. the most significant difference is that indoors, loT nodes can usually be powered via the power grid and can use a fixed communication infrastructure (eg, Ethernet, WiFi access points) [77]. However, if you are outdoors, loT nodes are more dependent on batteries and need to exchange data over relatively long distances (at least several hundred meters, up to 2 kilometers) Wifi which has the IEEE IEEE $802.11 \mathrm{a} / \mathrm{b} / \mathrm{g} / \mathrm{n} / \mathrm{ac}$ standard is one of the technologies that is highly incarnated to support intelligent learning in terms of connectivity [78]. In addition, a Bluetooth Beacon is also one that could be suggested to support this intelligent learning [79], but it is often restricted to indoor environments due to dense network deployments and complex network management [80]. The popularity of cell phones as the main telephone communication medium (ie, 2G / 3G / 4G) is highly recommended for providing intelligent learning services [81]. The use of $5 \mathrm{G}$ technology [82] is also expected to be able to provide communication services quickly and reduce response latency in smart learning applications [83].

In intelligent learning short distance communication can also be useful. For example, an ANT transceiver for monitoring performance developments [84]. Table 1 compares the most relevant communication technologies for use in smart learning solutions. The table also shows whether the references provided detail the network planning of the proposed solutions and, as can be observed, only a few works provide details about them.

\begin{tabular}{|c|c|c|c|c|c|}
\hline Technology & $\begin{array}{l}\text { Data } \\
\text { Rate }\end{array}$ & Main Features & $\begin{array}{l}\text { Frequency } \\
\text { Band }\end{array}$ & \begin{tabular}{|l|} 
Maximum \\
Range
\end{tabular} & $\begin{array}{l}\text { Typical Smart } \\
\text { Education } \\
\text { Application }\end{array}$ \\
\hline $\begin{array}{l}\text { Wi-Fi (IEEE } \\
802.11 \mathrm{~b} / \mathrm{g} / \mathrm{n} / \mathrm{a} \\
\text { c) }\end{array}$ & $\begin{array}{l}\text { up to } 440 \\
\text { Mbit/s } \\
\text { (one } \\
\text { stream) }\end{array}$ & $\begin{array}{l}\text { High power (battery can last } \\
\text { for hours), high speed, can } \\
\text { be located everywhere }\end{array}$ & 2.4-5 GHz & $<150 \mathrm{~m}$ & $\begin{array}{l}\text { Internet } \\
\text { broadband } \\
\text { access }\end{array}$ \\
\hline ANT+ & $20 \mathrm{kbit} / \mathrm{s}$ & $\begin{array}{l}\text { Consumes quite low power, } \\
\text { around } 63,440 \text { nodes }\end{array}$ & $2.4 \mathrm{GHz}$ & $<30 \mathrm{~m}$ & $\begin{array}{l}\text { Health and sport } \\
\text { performance } \\
\text { monitoring }\end{array}$ \\
\hline HF RFID & $\begin{array}{l}<640 \\
\text { kbit/s }\end{array}$ & $\begin{array}{l}\text { Inexpensive cost, generally } \\
\text { does not use batteries }\end{array}$ & $\begin{array}{l}3-30 \mathrm{MHz} \\
(13.56 \\
\mathrm{MHz})\end{array}$ & $\begin{array}{l}\text { a few } \\
\text { meters }\end{array}$ & $\begin{array}{l}\text { User and asset } \\
\text { identification for } \\
\text { access control } \\
\text { and payments }\end{array}$ \\
\hline $\begin{array}{l}\text { Bluetooth } 5 \\
\text { LE }\end{array}$ & $\begin{array}{l}1360 \\
\text { kbit/s }\end{array}$ & $\begin{array}{l}\text { Monitor from user flow } \\
\text { power, } \\
\text { telemetry, guidance }\end{array}$ & $2.4 \mathrm{GHz}$ & $<400 \mathrm{~m}$ & \begin{tabular}{|lr} 
Low & power \\
(batteries & last \\
from days & to
\end{tabular} \\
\hline
\end{tabular}




\begin{tabular}{|c|c|c|c|c|c|}
\hline & & & & & weeks) \\
\hline NB-loT & $\begin{array}{l}<250 \\
\text { kbit/s }\end{array}$ & $\begin{array}{l}\text { Low power and has a great } \\
\text { distance }\end{array}$ & $\begin{array}{l}\text { LTE } \\
\text { frequencie } \\
\text { S }\end{array}$ & $<35 \mathrm{~km}$ & IoT applications \\
\hline $\begin{array}{l}\text { DASH7/ISO } \\
18000-7\end{array}$ & $\begin{array}{l}27.8 \\
\mathrm{kbit} / \mathrm{s}\end{array}$ & $\begin{array}{l}\text { Has a fairly low power (the } \\
\text { battery can last from } \\
\text { months to years) }\end{array}$ & $\begin{array}{l}315-915 \\
\mathrm{MHz}\end{array}$ & $<10 \mathrm{~km}$ & \begin{tabular}{|lr} 
Item, & vehicle \\
and & user \\
tracking &
\end{tabular} \\
\hline ZigBee, & $\begin{array}{l}20-250 \\
\text { kbit/s }\end{array}$ & $\begin{array}{l}\text { The power used is so low } \\
\text { that the battery can last for } \\
\text { months or even years), up } \\
\text { to } 65,624 \text { nodes }\end{array}$ & $\begin{array}{ll}868-915 \\
\mathrm{MHz} & 2.4 \\
\mathrm{GHz} & \end{array}$ & $<100 \mathrm{~m}$ & $\begin{array}{l}\text { Wireless sensor } \\
\text { network } \\
\text { applications, } \\
\text { home } \\
\text { automation and } \\
\text { smart building } \\
\text { applications }\end{array}$ \\
\hline $\begin{array}{l}\text { Wi-Fi } \\
\text { HaLow/IEEE } \\
802.11 \text { ah }\end{array}$ & $\begin{array}{l}100 \mathrm{kbit} / \mathrm{s} \\
\text { per } \\
\text { channel }\end{array}$ & Low power & $\begin{array}{l}868-915 \\
\mathrm{MHz}\end{array}$ & $<1 \mathrm{~km}$ & IoT applications \\
\hline $\begin{array}{l}\text { LoRa, } \\
\text { LoRaWAN }\end{array}$ & $\begin{array}{l}0.25-50 \\
\text { kbit/s }\end{array}$ & $\begin{array}{l}\text { low power consumption, } \\
\text { has a long coverage area }\end{array}$ & $\begin{array}{l}\text { Different } \\
\text { Industrial } \\
\text { Scientific } \\
\text { Medical } \\
\text { bands }\end{array}$ & kilometers & IoT applications \\
\hline LF RFID & $\begin{array}{l}<640 \\
\mathrm{kbit} / \mathrm{s}\end{array}$ & $\begin{array}{c}\text { Low cost, and no need to } \\
\text { use batteries }\end{array}$ & $\begin{array}{c}30-300 \\
\mathrm{KHz}(125 \\
\mathrm{KHz})\end{array}$ & $<10 \mathrm{~cm}$ & $\begin{array}{l}\text { Access control } \\
\text { systems, asset } \\
\text { tracking }\end{array}$ \\
\hline NFC & $424 \mathrm{kbit} / \mathrm{s}$ & $\begin{array}{c}\text { Low cost, and no need to } \\
\text { use batteries }\end{array}$ & 13.56 MHz & $<20 \mathrm{~cm}$ & $\begin{array}{l}\text { User access } \\
\text { control and } \\
\text { payments }\end{array}$ \\
\hline $\begin{array}{c}\text { WirelessHAR } \\
\mathrm{T}\end{array}$ & $250 \mathrm{kbit} / \mathrm{s}$ & $\begin{array}{l}\text { Compatibility with the } \\
\text { HART protocol }\end{array}$ & $2.4 \mathrm{GHz}$ & $<10 m$ & $\begin{array}{l}\text { loT sensing } \\
\text { applications }\end{array}$ \\
\hline
\end{tabular}

Table 1. Most relevant communication technology

\section{(c). Hot Research Topic}

Since repeated testing of keywords can easily and precisely describe the research space and central substance of a particular subject, this paper then builds several event organizations with keywords, generally laying out the field of blockchain research. As shown in Figure 4,5,6 with detail Figure 4 shows Network Visualization, Figure 5 shows Overlay Visualization, Figure 6 shows Density Visualization, this information space map is based on titles and abstracts where the author has conducted research from 1000 block chain papers. , plotted using VOSviewer programming (border settings: check type: title and abstract fields; calculation technique: binary counting; choose threshold: 7 Occurrences; hub type: block chain). 


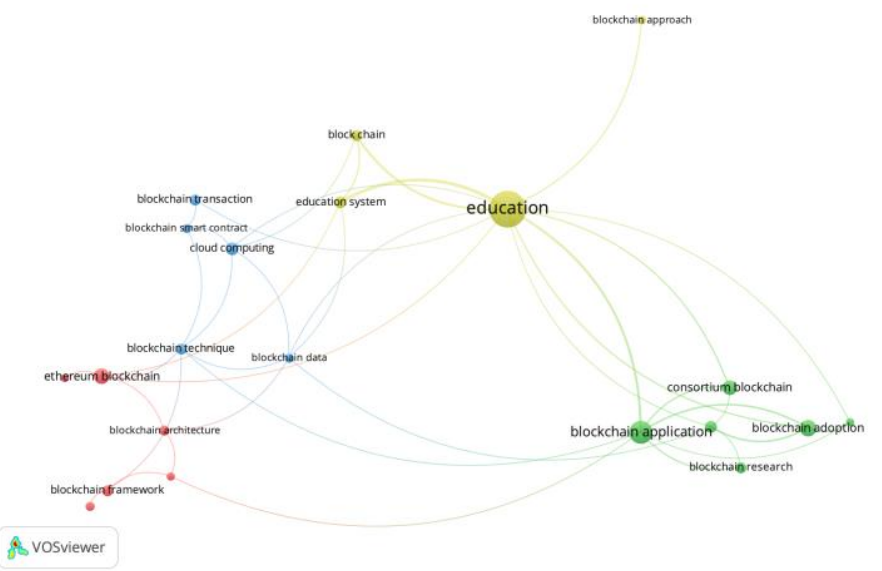

Figure 4. Network Visualization.

Based on Figure 4, there are 4 clusters marked by red in cluster 1, green in cluster 2 , blue in cluster 3 and yellow in cluster 4 . From these data, clusters 1 and 2 have the most items than the other clusters. others, but cluster 4 has items that seem to dominate compared to the others, namely education takes a fairly large role and has 12 linkages with other clusters. This shows that education can now be accompanied by the presence of this blockchain technology which will make the world of education even more rapid and sophisticated.

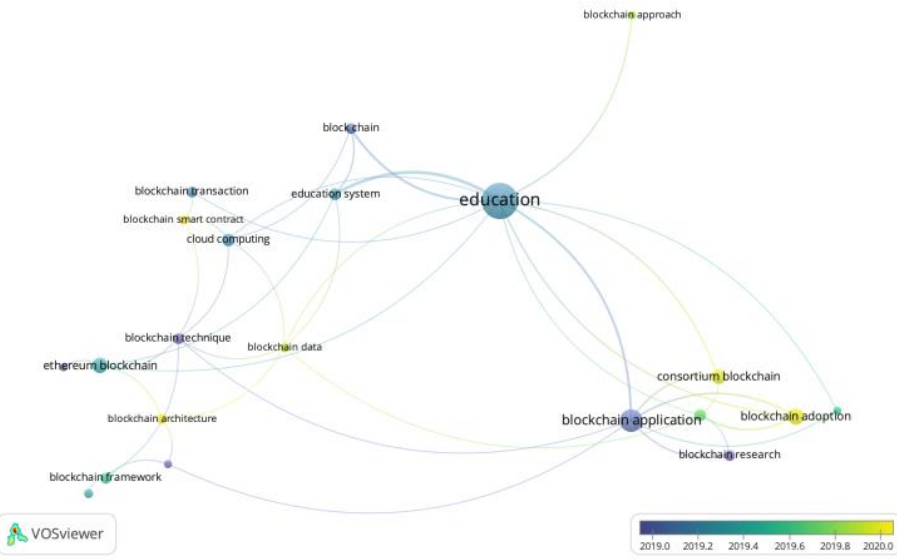

Figure 5. Overlay Visualization

Figure 5, explains how the time of the research was carried out. The 901 papers that the authors have collected were published in 2019 to 2020 so that a value range between 2019.0 to 2020.0 is created which describes the year of research In 2019 , which is depicted in blue, there have been articles discussing the relationship between blockchain and education but it is still in a small scope, the middle of the year marked in green is increasingly emerging research on blockchain technology which is increasingly specific in discussing other functions that can be used. take advantage of this blockchain technology, and in 2020 which is marked by yellow then research will appear on the adoption of blockchain which summarizes previous research, but this is still not much, therefore the author wants to contribute to increasing research on education that utilizes this blockchain technology. 


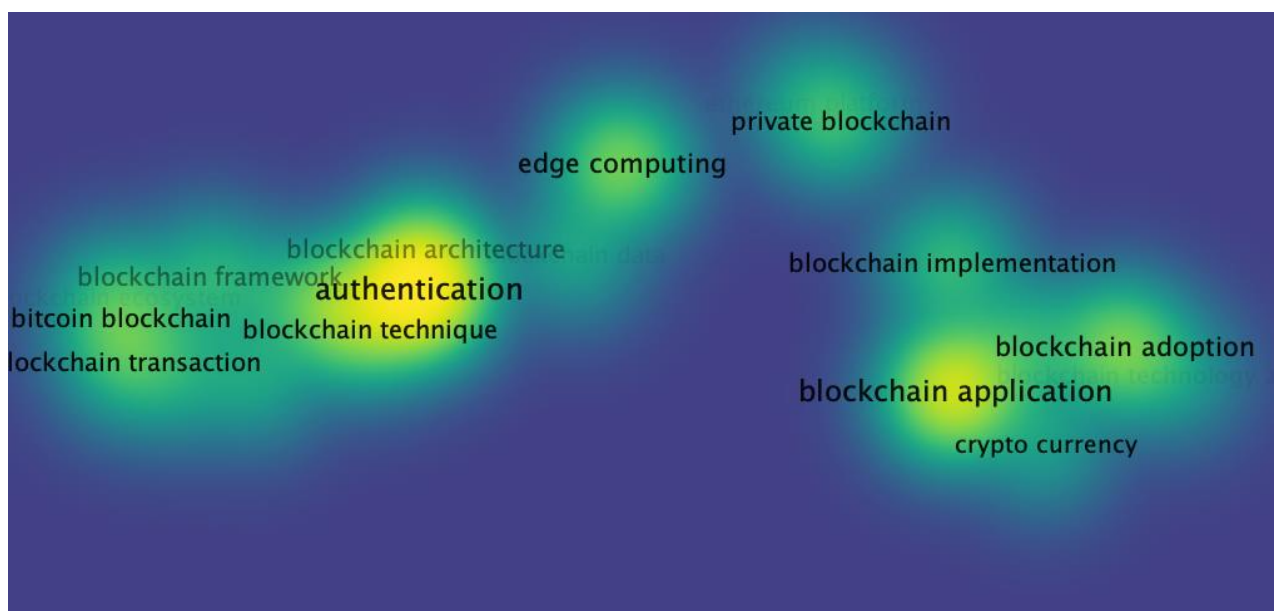

Figure 6. Density Visualization

Figure 6 shows the results of research on how many topics are discussed, the more yellow they will be. From these data it can be concluded that the blockchain topic is still less attractive with the least yellow color scale it has, education is still the main topic in the topics discussed, this is what makes the author increasingly challenged to make research on the relationship of education that can be developed again using This blockchain technology remembers its extraordinary abilities but is still rarely explored by many people.

\section{Conclusion}

This article discusses how the current role of technology can have a major impact on the world of education in realizing the concept of intelligent learning. After analyzing various methods of other universities in carrying out intelligent learning, the potential for loT, blockchain, architecture, and the latest communication paradigm can be used as a solution to build an intelligent learning application. Lastly, the main challenges that can be listed are for future university planners, IoT vendors, and developers for the next generation of intelligent learning.

\section{References}

[1] A. S. Bist, W. Febriani, C. Lukita, S. Kosasi, and U. Rahardja, "Design of Face Recognition AttendX for Recording Student Attendance Data Based on Artificial Intelligence Technology," Solid State Technol., vol. 63, no. 2s, 2020.

[2] T. Hariguna and T. Wahyuningsih, "Perancangan Ajri Learning Journal Center Menggunakan Tools Invision Untuk Mewujudkan Creative Innovation Soft Skill," $A D I$ Bisnis Digit. Interdisiplin J, vol. 1, no. 1, pp. 1-9, 2020.

[3] P. A. Sunarya, U. Rahardja, L. Sunarya, and M. Hardini, "The Role Of Blockchain As A Security Support For Student Profiles In Technology Education Systems," InfoTekJar J. Nas. Inform. dan Teknol. Jar., vol. 4, no. 2, pp. 203-207, 2020.

[4] S. Sudaryono, U. Rahardja, and D. Apriani, "The CICES Journal Governance Performance Improvement on Quality of Current Issues (Case Study of STMIK RAHARJA)," Aptisi Trans. Manag., vol. 3, no. 1, pp. 57-64, 2019.

[5] A. Chadha, "Notice of Retraction Dynamic clustering of data with modified K-prototype algorithm," Aptikom J. Comput. Sci. Inf. Technol., vol. 3, no. 2, pp. 37-46, 2018.

[6] A. Williams and E. Dolan, "Application of Blockchain Technology in e-LoA Technopreneurship Journal," Aptisi Trans. Technopreneursh., vol. 2, no. 1, pp. 98-103, 2020.

[7] U. Rahardja, A. Moein, and N. Lutfiani, "Leadership, competency, working motivation and performance of high private education lecturer with institution accreditation B: Area kopertis IV Banten province," Man India, vol. 97, no. 24, pp. 179-192, 2018.

[8] E. S. N. Aisyah and O. Y. Keat, "Utilization of Online Accounting Software As A Supplier 
Data Collection System At The Company," Aptisi Trans. Manag., vol. 1, no. 2, pp. 8085, 2017.

[9] R. Ade, "The Influence of Experimental Methods Against the Process Skills Science Grade IV Elementary School YOGYAKARTA Golo," Aptisi Trans. Manag., vol. 3, no. 1, pp. 29-35, 2019.

[10] E. Febriyanto, R. S. Naufal, and S. Sulistiawati, "Planning of the Web-based E-Raport Assessment System," Aptisi Trans. Technopreneursh., vol. 2, no. 1, pp. 48-58, 2020.

[11] U. Rahardja, Q. Aini, and A. Khoirunisa, "The Effect of Rinfogroups as a Discussion Media in Student Learning Motivation," Aptisi Trans. Manag., vol. 2, no. 1, pp. 79-88, 2018.

[12] A. B. Wandanaya and D. Rahmasary, "The Impact Analysis Of Stock Reminder Of Goods To Quality Company," Aptisi Trans. Manag., vol. 3, no. 2, pp. 142-148, 2019.

[13] H. Henderi, S. R. Zuliana, and R. A. Pradana, "Periodic Data Analysis and Forecasting As An Overview of Future Management Economics," Aptisi Trans. Manag., vol. 3, no. 1, pp. 73-83, 2019.

[14] Q. Aini, A. Anoesyirwan, and Y. Ana, "Effect of Cloud Accounting as income statement on Accountant Performance," Aptisi Trans. Manag., vol. 4, no. 1, pp. 13-21, 2020.

[15] C. P. Latha and M. Priya, "A review on deep learning algorithms for speech and facial emotion recognition," APTIKOM J. Comput. Sci. Inf. Technol., vol. 1, no. 3, pp. 92-108, 2016.

[16] M. Yusup, R. S. Naufal, and M. Hardini, "Management of utilizing data analysis and hypothesis testing in improving the quality of research reports," Aptisi Trans. Manag., vol. 2, no. 2, pp. 159-167, 2018.

[17] U. Rahardja, E. P. Harahap, and S. R. Dewi, "The strategy of enhancing article citation and $\mathrm{H}$-index on SINTA to improve tertiary reputation," TELKOMNIKA, vol. 17, no. 2, pp. 683-692, 2019.

[18] W. Hidayat, B. Pramono, and M. Afdulloh, "System Analysis Of Inventory Information On Raw Material Companies," Aptisi Trans. Manag., vol. 3, no. 2, pp. 126-130, 2019.

[19] U. Rahardja, D. Andayani, N. C. Aristo, and Z. A. Hasibuan, "Application Of Trial Finalization System As Determinants Of Final Thesis Session Results," IAIC Trans. Sustain. Digit. Innov., vol. 1, no. 1, pp. 1-7, 2019.

[20] S. N. Abdulwahid, "Development of an efficient mechanism for rapid protocols using NS2 simulator," APTIKOM J. Comput. Sci. Inf. Technol., vol. 3, no. 1, pp. 13-20, 2018.

[21] F. Alfiah, R. Sudarji, and D. T. Al Fatah, "Aplikasi Kriptografi Dengan Menggunakan Algoritma Elgamal Berbasis Java Desktop Pada Pt. Wahana Indo Trada Nissan Jatake," ADI Bisnis Digit. Interdisiplin J., vol. 1, no. 1 Juni, pp. 22-34, 2020.

[22] U. Rahardja, "Artificial informatics," in 2009 4th IEEE Conference on Industrial Electronics and Applications, 2009, pp. 3064-3067.

[23] A. Asmawati, F. J. E. Putra, and L. Richie, "Control Led Through Internet Based On Nodemcu With Blynk Application,” Aptisi Trans. Technopreneursh., vol. 1, no. 2, pp. 170-179, 2019.

[24] Q. Aini, P. A. Sunarya, and A. S. Bein, "The Implementation Of Viewboard Of The Head Of Department As A Media For Student Information Is Worth Doing Final Research," IAIC Trans. Sustain. Digit. Innov., vol. 1, no. 1, pp. 18-25, 2019.

[25] F. Alfiah and A. Yondari, "Design Of Web-based Qr-code Absence At The Education Office," IAIC Trans. Sustain. Digit. Innov., vol. 1, no. 1, pp. 26-31, 2019.

[26] M. Sheshikala, D. R. Rao, and M. A. Kadampur, "An Improved Approximation Algorithm for Co-location Mining in Uncertain Data Sets using Probabilistic Approach," APTIKOM J. Comput. Sci. Inf. Technol., vol. 2, no. 1, pp. 1-7, 2017.

[27] I. Dhaniarti, I. Handayani, and E. W. Bachri, "The Utilization Management of Path Analysis Methods to Improve Quality in Writing Research Reports at Higher Education," Aptisi Trans. Manag., vol. 2, no. 2, pp. 121-128, 2018.

[28] S. Khanna, "ICT Enabled Learning: A tool in Crisis Management," Aptisi Trans. Technopreneursh., vol. 2, no. 2, pp. 127-130, 2020.

[29] A. C. Purnomo, B. Pramono, and F. P. Oganda, "Design of Information System in Admission of New Students Based on Web in SMK Al Amanah," Aptisi Trans. Manag., 
vol. 3, no. 2, pp. 159-167, 2019.

[30] F. Sudarto and A. Yondari, "Web-Based Population Cencus Design In Neighborhood Building," Aptisi Trans. Technopreneursh., vol. 2, no. 1, pp. 18-24, 2020.

[31] B. K. Nuhu, O. T. Arulogun, I. A. Adeyanju, and I. M. Abdullahi, "Wireless sensor network for real-time flood monitoring based on 6loWPAN communication standard," APTIKOM J. Comput. Sci. Inf. Technol., vol. 1, no. 1, pp. 12-22, 2016.

[32] N. Nasruddin, H. Umiyati, and K. R. Fadil, "The Optimization Management of Combination Research Methods in Improving the Quality of Writing Research Reports," Aptisi Trans. Manag., vol. 3, no. 1, pp. 36-45, 2019.

[33] S. Basuki and R. Anugrah, "Transaction Document Security Protection In The Form Of Image File, Jpg Or Tif Interbank Transfer Using Steganography And Cryptography," IAIC Trans. Sustain. Digit. Innov., vol. 1, no. 1, pp. 42-48, 2019.

[34] D. Amany and A. Desire, "Pembelajaran Interaktif berbasis Gamifikasi guna Mendukung Program WFH pada saat Pandemic Covid-19," ADI Bisnis Digit. Interdisiplin J., vol. 1, no. 1 Juni, pp. 48-55, 2020.

[35] Q. Aini, I. Dhaniarti, and A. Khoirunisa, "Effects of ilearning media on student learning motivation," Aptisi Trans. Manag., vol. 3, no. 1, pp. 1-12, 2019.

[36] Q. Aini, I. Handayani, and F. H. N. Lestari, "Utilization Of Scientific Publication Media To Improve The Quality Of Scientific Work," Aptisi Trans. Manag., vol. 4, no. 1, pp. 1-12, 2020.

[37] H. Hady, H. Henderi, and D. M. Putri, "The Application of Science Concepts in Management Research Reports Based on Scientific Truth," Aptisi Trans. Manag., vol. 2, no. 1, pp. 37-44, 2018.

[38] D. Mohammed, N. Aisha, A. Himki, A. Dithi, and A. Y. Ardianto, "Blockchain Is Top Skill For 2020," Aptisi Trans. Technopreneursh., vol. 2, no. 2, pp. 180-185, 2020.

[39] Q. A. Henderi, N. P. L. Santoso, A. Faturahman, and U. Rahardja, "A proposed gamification framework for smart attendance system using rule base," J. Adv. Res. Dyn. Control Syst, vol. 12, no. 2, pp. 1827-1838, 2020.

[40] U. Rahardja, A. S. Bist, M. Hardini, Q. Aini, and E. P. Harahap, "Authentication of Covid19 Patient Certification with Blockchain Protocol," Int. J. Adv. Sci Technol, vol. 29, no. 8s, pp. 4015-4024, 2020.

[41] Q. Aini, A. Badrianto, F. Budiarty, A. Khoirunisa, and U. Rahardja, "Alleviate fake diploma problem in education using block chain technology," J. Adv. Res. Dyn. Control Syst, vol. 12, no. 2, pp. 1821-1826, 2020.

[42] Q. Aini, S. R. Bob, N. P. L. Santoso, A. Faturahman, and U. Rahardja, "Digitalization of Smart Student Assessment Quality in Era 4.0," Int. J. Adv. Trends Comput. Sci. Eng, vol. 9, no. 1.2, pp. 257-265, 2020.

[43] B. S. Riza, "Blockchain Dalam Pendidikan: Lapisan Logis di Bawahnya," ADI Bisnis Digit. Interdisiplin J., vol. 1, no. 1 Juni, pp. 41-47, 2020.

[44] S. Kosasi, "Karakteristik Blockchain Teknologi Dalam Pengembangan Edukasi," ADI Bisnis Digit. Interdisiplin J, vol. 1, no. 1, pp. 87-94, 2020.

[45] C. Lukita, M. Hatta, E. P. Harahap, and U. Rahardja, "Crowd funding management platform based on block chain technology using smart contracts," J. Adv. Res. Dyn. Control Syst, vol. 12, no. 2, pp. 1928-1933, 2020.

[46] U. Rahardja, Q. Aini, Y. I. Graha, and M. R. Tangkaw, "Gamification Framework Design of Management Education and Development in Industrial Revolution 4.0," in Journal of Physics: Conference Series, 2019, vol. 1364, no. 1, p. 12035.

[47] I. Amsyar, E. Christopher, A. Dithi, A. N. Khan, and S. Maulana, "The Challenge of Cryptocurrency in the Era of the Digital Revolution: A Review of Systematic Literature," Aptisi Trans. Technopreneursh., vol. 2, no. 2, pp. 153-159, 2020.

[48] Q. Aini, U. Rahardja, and A. Khoirunisa, "Blockchain Technology into Gamification on Education," IJCCS (Indonesian J. Comput. Cybern. Syst., vol. 14, no. 2, pp. 147-158, 2020.

[49] U. Rahardja, A. N. Hidayanto, T. Hariguna, and Q. Aini, "Design framework on tertiary education system in Indonesia using blockchain technology," in 2019 7th International Conference on Cyber and IT Service Management (CITSM), 2019, vol. 7, pp. 1-4. 
[50] S. Sudaryono, Q. Aini, N. Lutfiani, F. Hanafi, and U. Rahardja, "Application of Blockchain Technology for iLearning Student Assessment," IJCCS (Indonesian J. Comput. Cybern. Syst., vol. 14, no. 2, pp. 209-218, 2020.

[51] S. Watini, Q. Aini, M. Hardini, and U. Rahardja, "Improving Citizen's Awareness in Conserving Diversity of Malay Traditional Dances in Malaysia through the Art Appreciation Performed by Students of Early Childhood Education Study Program," Int. J. Psychosoc. Rehabil, vol. 24, no. 8, pp. 2730-2737, 2020.

[52] N. Lutfiani, F. P. Oganda, C. Lukita, Q. Aini, and U. Rahardja, "Desain dan Metodologi Teknologi Blockchain Untuk Monitoring Manajemen Rantai Pasokan Makanan yang Terdesentralisasi," InfoTekJar J. Nas. Inform. dan Teknol. Jar., vol. 5, no. 1, pp. 18-25, 2020.

[53] I. Handayani, R. Supriati, and E. S. N. Aisyah, "Proof of Blockchain Work on The Security of Academic Certificates," in 2020 8th International Conference on Cyber and IT Service Management (CITSM), 2020, pp. 1-5.

[54] Z. Fauziah, H. Latifah, X. Omar, A. Khoirunisa, and S. Millah, "Application of Blockchain Technology in Smart Contracts: A Systematic Literature Review," Aptisi Trans. Technopreneursh., vol. 2, no. 2, pp. 160-166, 2020.

[55] A. K. Yaniaja, H. Wahyudrajat, and V. T. Devana, "Pengenalan Model Gamifikasi ke dalam E-Learning Pada Perguruan Tinggi," ADI Pengabdi. Kpd. Masy., vol. 1, no. 1, pp. 22-30, 2020.

[56] D. Supriyanti, C. S. Kesumawati, and S. Maryam, "Design Information System Stock Inventory To Manage Data Of Goods (Case Study: PT Monier)," Aptisi Trans. Manag., vol. 4, no. 1, pp. 22-31, 2020.

[57] M. Mardiana, N. Lutfiani, and R. S. Saga, "The Online Sales Application Of Black And White Print Based On Yii Framework On Higher Education E-Commerce Website," Aptisi Trans. Technopreneursh., vol. 1, no. 2, pp. 118-127, 2019.

[58] R. Harjanto, E. B. P. Manurung, and A. D. Lestari, "Optimization of Proposal Management Arrangements as Learning Tools in Scientific Research Activities," Aptisi Trans. Manag., vol. 2, no. 1, pp. 55-62, 2018.

[59] P. Ramanathan, "Implementation of PC Controlled Wireless Video Transmitting Vehicle," APTIKOM J. Comput. Sci. Inf. Technol., vol. 2, no. 2, pp. 63-67, 2017.

[60] A. Adiyanto and R. Febrianto, "Authentication Of Transaction Process In E-marketplace Based On Blockchain?? technology," Aptisi Trans. Technopreneursh., vol. 2, no. 1, pp. 68-74, 2020.

[61] A. S. Bein, Y. I. Graha, and A. P. Pangestu, "Pandawan Website Design Based Content Management System As Media E-commerce Transaction," Aptisi Trans. Technopreneursh., vol. 2, no. 1, pp. 87-97, 2020.

[62] E. Febriyanto, R. S. Naufal, and F. Budiarty, "Attitude Competency Assessment in the 2013 curriculum based on elementary school Prototyping methods," IAIC Trans. Sustain. Digit. Innov. 1st Ed. Vol. 1 No. 1 Oct. 2019, p. 87, 2021.

[63] N. Nawindah and L. Fajarita, "Peningkatan Sumber Daya Manusia Melalui Pembuatan Blog Bagi Siswa Pusat Kegiatan Belajar Masyarakat," ADI Pengabdi. Kpd. Masy., vol. 1, no. 1, pp. 87-90, 2020.

[64] T. Alam, "Cloud Computing and its role in the Information Technology," IAIC Trans. Sustain. Digit. Innov., vol. 1, pp. 108-115, 2021.

[65] R. A. N. Yuniati, L. S. Rabbani, and M. S. A. Putri, "Study of Comparison of Stock Performance Before And After Doing Split Stock In Go Public Companies That Are Listing on The Idx Period 2013-2015," Aptisi Trans. Technopreneursh., vol. 2, no. 1, pp. 1-17, 2020.

[66] Y. Anggara, "Cegah COVID-19 Di Era New Normal Pada KP. Sambengan," ADI Pengabdi. Kpd. Masy., vol. 1, no. 1, pp. 59-68, 2020.

[67] T. Hariguna, E. P. Harahap, and S. Salsabila, "Implementation of Business Intelligence Using Highlights in the YII Framework based Attendance Assessment System," Aptisi Trans. Technopreneursh., vol. 1, no. 2, pp. 109-116, 2019.

[68] D. A. Kurniawan and A. Z. Santoso, "Pengelolaan Sampah di daerah Sepatan Kabupaten Tangerang," ADI Pengabdi. Kpd. Masy., vol. 1, no. 1, pp. 31-36, 2020. 
[69] W. Zulkarnain and S. Andini, "Inkubator Bisnis Modern Berbasis I-Learning Untuk Menciptakan Kreativitas Startup di Indonesia," ADI Pengabdi. Kpd. Masy., vol. 1, no. 1, pp. 77-86, 2020.

[70] M. Aziz and M. Aman, "Decision Support System For Selection Of Expertise Using Analytical Hierarchy Process Method," IAIC Trans. Sustain. Digit. Innov., vol. 1, no. 1, pp. 49-65, 2019.

[71] G. N. B. Safrizal and G. N. Budiadyana, "Analysis Application Design Career Development Center In The STMIK Insan Pembangunan and (Case Study: Information Study Program)," IAIC Trans. Sustain. Digit. Innov. 1st Ed. Vol. 1 No. 1 Oct. 2019, p. 66, 2021.

[72] K. Rasyid and T. A. Pambudi, "Single-plate Swipe Couplings On Four-wheeled Vehicles," Aptisi Trans. Technopreneursh., vol. 2, no. 1, pp. 25-33, 2020.

[73] R. Hardjosubroto, U. Rahardja, N. Anggraini, and W. Yestina, "Penggalangan Dana Digital Untuk Yayasan Disabilitas Melalui Produk UMKM Di Era 4.0," ADI Pengabdi. Kpd. Masy., vol. 1, no. 1, pp. 1-13, 2020.

[74] T. Hariguna, U. Rahardja, and Q. Aini, "Effect of social media activities to determinants public participate intention of e-government," Procedia Comput. Sci., vol. 161, pp. 233241, 2019.

[75] P. A. Sunarya and F. Andriyani, "Henderi, and U. Rahardja,'Algorithm automatic full time equivalent, case study of health service,"” Int. J. Adv. Trends Comput. Sci. Eng, vol. 8, no. 1.5, pp. 387-391.

[76] S. Alfeno and D. Rifai, "Utilization of the Django Framework as a Dashboard Model Information System for Raw Material Inventory on PT Bimasakti Karyaprima," Aptisi Trans. Technopreneursh., vol. 1, no. 2, pp. 192-202, 2019.

[77] A. Soliga and G. Jasil, "Evaluating Blind Image Quality Using RBF Neural Network," Aptikom J. Comput. Sci. Inf. Technol., vol. 1, no. 1, pp. 23-26, 2016.

[78] S. H. Rukmana and M. A. Muslim, "Decision Support System Based on Benefit Cost Ratio Method for Project Tender," APTIKOM J. Comput. Sci. Inf. Technol., vol. 2, no. 1, pp. 26-30, 2017.

[79] H. Haris and N. Priliasari, "The design of web-based training management information systems at PT. Sintech Berkah Abadi," ADI J. Recent Innov., vol. 2, no. 2, pp. 216-222, 2021.

[80] K. Khasanah, "The Effect of Lecturer Professionalism And Teaching Motivation on Lecturers Strengthening The Nation's Competitiveness (Survey on XYZ College Lecturers in Central Jakarta City)," ADI J. Recent Innov., vol. 2, no. 1, pp. 66-71, 2020. 